\title{
Use of a Bridge for Day Roosting by the Hoary Bat, Lasiurus cinereus
}

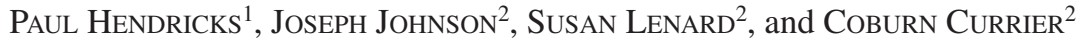 \\ ${ }^{1}$ Montana Natural Heritage Program, 909 Locust Street, Missoula, Montana 59802 USA \\ ${ }^{2}$ Montana Natural Heritage Program, 1515 East Sixth Avenue, Helena, Montana 59620-1800 USA
}

Hendricks, Paul, Joseph Jobnson, Susan Lenard, and Coburn Currier. 2004. Use of a bridge for day roosting by the Hoary Bat, Lasiurus cinereus. Canadian Field-Naturalist 119(1): 132-133.

The Hoary Bat (Lasiurus cinereus) is a migratory species with the widest distribution of all New World bats. It is a solitary species that roosts during the day and night primarily among tree foliage. During a survey of 130 highway structures (bridges and culverts) in south central Montana for evidence of use by bats, we discovered a female Hoary Bat with young in mid July 2003 using a wooden bridge as a day roost. This is the first report of Hoary Bats using a bridge as roosting habitat.

Key Words: Hoary Bat, Lasiurus cinereus, roosting, habitat, bridge use, Montana.

The Hoary Bat (Lasiurus cinereus) has the widest distribution of all New World bats (Shump and Shump 1982). Across their range males and females tend to roost alone (Constantine 1966; Barbour and Davis 1969; van Zyll de Jong 1985; Nagorsen and Brigham 1993). Roosting individuals are encountered infrequently in deciduous and coniferous tree foliage, the preferred roosting habitat, and much remains to be learned about their roosting habits.

During July and August 2003 we examined 130 highway structures (bridges and culverts) in Carbon, Stillwater, and Yellowstone counties, south central Montana, for evidence of use by bats as day or night roosts. Twelve bridges were used as day roosts by four species of bats. Two bridges supported maternity colonies of Little Brown Myotis (Myotis lucifugus), and two harbored maternity colonies of Big Brown Bats (Eptesicus fuscus). We estimated these colonies included 15-90 adults; at the remaining eight bridges we found 1-8 individual bats. Bat species present among the 12 bridge day roosts included Big Brown Bat at ten, Little Brown Myotis at two, Western Small-footed Myotis (M. ciliolabrum) at two, and Hoary Bat at one.

On 16 July at about 11:00, we discovered a female Hoary Bat roosting in a bridge spanning Shane Creek (45'36'42.7"N, 109 16'48.7"W; 1125 m elevation) on Montana Highway 78, about $4.8 \mathrm{~km} \mathrm{~S}$ of Columbus, Stillwater County. She was wedged in a tapering $4 \mathrm{~cm}$ wide slot (ca. $20 \mathrm{~cm}$ deep) between two wooden girders on the underside of the bridge $5.3 \mathrm{~m}$ above bare ground (Figure 1); only a shallow narrow channel of water was flowing under the bridge at the time. Using an $8 \times$ binocular and spotlight we could see at least two naked pups partially exposed and crawling under her folded wings. A maternity colony of about 15 adult Big Brown Bats occupied the same slot $1.5 \mathrm{~m}$ from the female Hoary Bat but where the slot was slightly narrower.

The bridge was a two-lane wooden girder design (19.8 m long) with an asphalt deck surface, and provided roosting sites similar to some railroad bridges (see Davis and Cockrum 1963). Vegetation adjacent to the bridge included a riparian strip of Plains Cottonwood (Populus deltoides) and willow (Salix sp.), and pasture intermixed with rural home development; nearby sandstone bluffs supported open stands of Ponderosa Pine (Pinus ponderosa). We revisited the bridge the two days following discovery of the female Hoary Bat, as well as on 18 August, 9 and 16 September, but no Hoary Bat was present on any of these days, although about 15 Big Brown Bats continued to use the bridge as a day roost until the last date, when none was present.

Records of Hoary Bats roosting in sites other than tree foliage are unusual, and use of man-made structures is rare. Appearance in caves is the most frequently reported alternative roost site, but Hoary Bats found in caves usually are dead or dying individuals (Mumford 1953; Beer 1954; Myers 1960). Other reported roosting sites include a squirrel nest, a woodpecker cavity, a tree hollow, a driftwood plank, a cellar door, and the side of a building (Bailey 1936; Neill 1952; Shump and Shump 1982; Nagorsen and Brigham 1993).

Use of bridges by Hoary Bats for day or night roosting has not been reported previously in the literature. Ellison et al. (2003) mention collection of a Hoary Bat at a bridge, but this is based on a specimen (MSU5676 at Montana State University, Bozeman) taken at "Shedd's Bridge" in Gallatin County, Montana on 11 September 1964; no data associated with the specimen indicate that it was roosting in the bridge. The Hoary Bat was not among the 17 bat species found during a broad survey of 2421 highway structures (bridges and culverts) across the western and southern United States (Keeley and Tuttle 1999). Studies of smaller samples of bridges in Arizona, northern California, and the Oregon Coast Range also did not report the presence of Hoary Bats (Davis and Cockrum 1963; Pierson et al. 1996; Adam and Hayes 2000).

Lack of prior reports of Hoary Bats using bridges for roosting (Shump and Shump 1982; Pierson et al. 1996; Keeley and Tuttle 1999) indicates that bridge use by this species is a relatively rare occurrence. The Hoary Bat is a solitary roosting species that switches roosts frequently (Lewis 1995); this could make detection of their use of any particular highway structure highly unlikely. Bridge surveys often involve only one or a few 


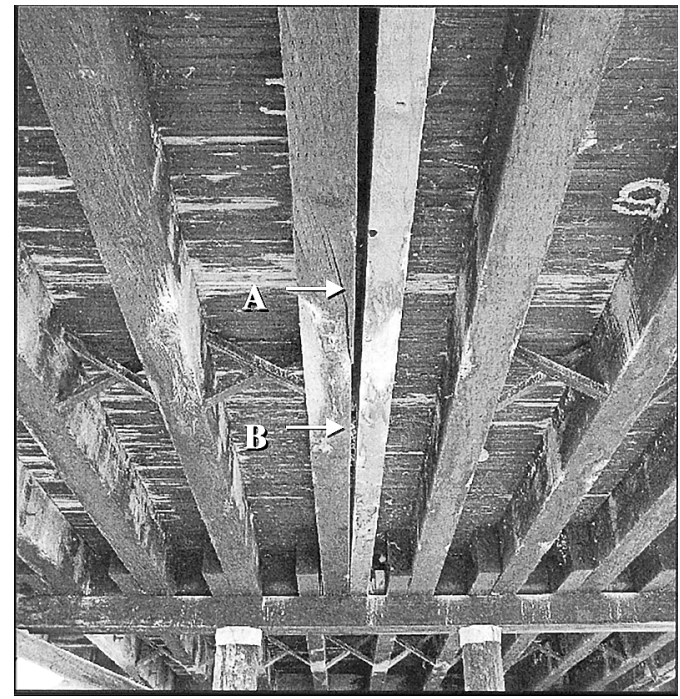

FIGURE 1. Underside of wooden bridge spanning Shane Creek, Stillwater County, Montana, showing July 2003 dayroost locations of a female Hoary Bat (A) and a maternity colony of Big Brown Bats (B).

visits to specific structures (Davis and Cockrum 1963; Keeley and Tuttle 1999; Adam and Hayes 2000; this study), or else monitor activity more intensively at a small number of structures (Davis and Cockrum 1963; Pierson et al. 1996; Adam and Hayes 2000); the number of bridge visits or scope of intensive surveys may be inadequate to detect an extremely low frequency of bridge use by the Hoary Bat. Studies that focus on bridges known to be used as night roosts (Pierson et al. 1996; Adams and Hayes 2000) may overlook Hoary Bats if their use of bridges is more likely during the day, the time when we made our observation. Thus, low roost site fidelity and a solitary nature may make detecting the rare occupancy of bridges by Hoary Bats even more problematic if only single visits to bridges are made during daytime surveys, or studies are focused primarily or exclusively on night roost dynamics.

\section{Acknowledgments}

Our observations were made during a cost reimbursement contract (MDT Project \#8159) between the Montana Department of Transportation and Montana State Library-Natural Resource Information System/ Montana Natural Heritage Program. The opinions, findings, and conclusions expressed in this publication are those of the authors and not necessarily those of the Montana Department of Transportation or the Federal Highway Administration. We thank Susan Sillick (MDT) and Jim Hill (NRIS) for administering this contract, and Larry Urban (MDT) for being receptive to the initial idea. Laura Ellison (US Geological Survey) identified the source of their bridge use record. Our paper benefited from the comments of two reviewers.

\section{Literature Cited}

Adam, M. D., and J. P. Hayes. 2000. Use of bridges as night roosts by bats in the Oregon Coast Range. Journal of Mammalogy 81: 402-407.

Bailey, V. 1936. The mammals and life zones of Oregon. North American Fauna 55. 416 pages.

Barbour, R. W., and W. H. Davis. 1969. Bats of America. University Press of Kentucky, Lexington, Kentucky. 286 pages.

Beer, J. R. 1954. A record of the hoary bat from a cave. Journal of Mammalogy 35: 116.

Constantine, D. G. 1966. Ecological observations on lasiurine bats in lowa. Journal of Mammalogy 47: 34-41.

Davis, R., and E. L. Cockrum. 1963. Bridges utilized as day-roosts by bats. Joumal of Mammalogy 44: 428-430.

Ellison, L. E., T. J. O'Shea, M. A. Bogan, A. L. Everette, and D. M. Schneider. 2003. Existing data on colonies of bats in the United States: summary and analysis of the U.S. Geological Survey's bat population database. Pages 127-237 in Monitoring trends in bat populations of the United States and territories: problems and prospects. U.S. Geological Survey, Biological Resources Division, Information and Technology Report USGS/BRD/ITR-20030003. Edited by T. J. O'Shea and M. A. Bogan. National Technical Information Service, Springfield, Virginia. 274 pages.

Keeley, B. W., and M. D. Tuttle. 1999. Bats in American bridges. Resource Publication 4. Bat Conservation International, Austin, Texas. 41 pages.

Lewis, S. E. 1995. Roost fidelity of bats: a review. Journal of Mammalogy 76: 481-496.

Mumford, R. E. 1953. Hoary bat skull in an Indiana cave. Journal of Mammalogy 34: 121.

Myers, R. F. 1960. Lasiurus from Missouri caves. Journal of Mammalogy 41: 114-117.

Nagorsen, D. W., and R. M. Brigham. 1993. Bats of British Columbia. UBC Press. Vancouver, British Columbia. 164 pages.

Neill. W. T. 1952. Hoary bat in a squirrel's nest Journal of Mammalogy 33: 113.

Pierson, E. D., W. E. Rainey, and R. M. Miller. 1996. Night roost sampling: a window on the forest bat community in northern California. Pages 151-163 in Bats and forests: proceedings of the Victoria Symposium. Edited by R. M. Barclay and R. M. Brigham. Ministry of Forests Research Program Working Paper 23/1996, Victoria, British Columbia. 292 pages.

Shump, K. A., Jr., and A. U. Shump. 1982. Lasiurus cinereus. Mammalian Species 185: 1-5.

van Zyll de Jong, C. G. 1985. Handbook of Canadian Mammals. 2. Bats. National Museum of Natural Sciences, Ottawa, Ontario. 212 pages.

Received 25 March 2004

Accepted 28 January 2005 